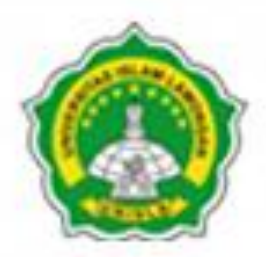

Available online at https://jurnalteknik.unisla.ac.id/index.php/CV

\title{
The Study On Utilization Waste Tire Seeds As Amixture Of Ac-Wc Asphalt On Road Pavement
}

\author{
Fauzan Adzim ${ }^{1}$,Zulkifli Lubis ${ }^{2}$, Bobby Damara ${ }^{3}$ \\ ${ }^{*}, 2,3$ Civil Engineering Study Program, Faculty of Engineering, Lamongan Islamic University. \\ Email : ${ }^{1}$ adzimfauzan565@gmail.com, ${ }^{2 *}$ cheppy.lubis@gmail.com. ${ }^{3}$ bobbydamara@ unisla.ac.id
}

\section{A R T I C LE IN F O}

\section{Article History :}

Article entry : 2021-09-30

Article revised : 2021-12-09

Article received : 2021-12-16

Keywords :

Waste Tires, Laston AC-WC, Marshall Test

IEEE Style in citing this article : F. Adzim, Z. Lubis and B. Damara, "The Study on Utilization Waste Tire Seeds as Amixture of Ac-Wc Asphalt on Road Pavement," CIVILA, vol. 6 , no. 2, pp. 257-266, 2021.

\section{A B S T R A C T}

\begin{abstract}
Aus-Layered Asphalt Concrete (AC-WC) is the topmost layer of the pavement structure that is directly related to the vehicle wheels. WC) in this study selected tire ore waste as an added material to the job mix. In this study, the variation of the mixture added with tire ore starting from $0 \%, 3 \%, 6 \%$ and $8 \%$ addition of tire ore waste for the highest variation value is $3 \%$, stability value is $494.99 \mathrm{~kg}$, Voids Filled With Asphalt's value is 68,40\%, value of Voids in Mix is 3.65\%, flow value is 3,21\%, value of Marshall Quotient is $154,61 \mathrm{~kg} / \mathrm{mm}$, Density's value is $2,29 \mathrm{gr} / \mathrm{cc}$. Finally, it was concluded that the addition of waste tire ore is not in accordance with SNI 06-2489-1991 because the higher percentage value in the mixture will decrease the value of Marshall Stability.
\end{abstract} search, or link to the full texts of its articles and allow readers to use them for any other lawful purpose. 


\section{Introduction}

Roads are the most dominant transportation infrastructure used, judging from the high intensity of road users[1][2], the maintenance and construction of roads must also have good quality and there must be innovation updates from time to time on the infrastructure of road construction[2][3].

Aus Layer Asphalt Concrete (AC-WC) is the topmost layer of the pavement structure that is directly related to the vehicle wheels[4][5], has a smoother texture than Intermediate Asphalt Concrete (AC-BC), in this study tire ore was chosen as an added material. Asphalt Lapis Aus (AC-WC) due to the lack of utilization of tire ore and the nature of the ore itself is elastic which is suitable to be mixed with Asphalt Lapis Aus (AC-WC)[5][6].

\section{Literature Review}

in previous research that has been carried out with the title "The Effect of Adding Waste Tire Powder as a Substitute for Fine Aggregate on the Stability of the AC-WC Layer. -WC)" containing granules/waste of tire powder and comparing with asphalt mixture without waste of tire powder[7].

The mixing method used in this study is the middle limit of the AC-WC mixture gradation in the requirements of Highways. 30 has an optimum asphalt content of 5.75\% and a mixture with $100 \%$ waste tire powder as a substitute for aggregate in fraction No. 30 has an optimum asphalt content of $6.05 \%$. The results of the Marshall Immersion test show the residual strength index of the AC-WC mixture with $50 \%$ waste tire powder as a partial substitute for aggregate in the No. fraction. 30, has the largest value of $95.49 \%$. The optimum mixture was obtained in a mixture containing waste tire powder as a substitute for fraction No. 30 as much as $56 \%$ by $95.645 \%$

\section{Research method}

In this research will do some stages in general. Starting with the preparation stage, the data collection stage, materials and equipment to be used such as waste tire ore, coarse aggregate, fine aggregate, asphalt, as well as test objects, then proceed to the data analysis stage and the last stage is drawing conclusions[8][9][10].

\subsection{Description and Technical}

\section{Data Collection Techniques}

In compiling this report, the researcher carried out several methods of collecting data, which included primary and secondary data collection at the time of the research[10]. 
Is the data obtained from the results of experiments / experiments in the laboratory. In this case, it includes data on aggregate inspection, asphalt inspection and inspection of test objects (briquettes)[11].

3. Interview

Interviews are data collection techniques that are carried out face-to-face and direct questions and answers to informants[12]. Like when before making a job mix formula. The researcher also asked directly to people who understood the process of making asphalt mixtures, especially to laboratory lecturers, and the head of the laboratory[13].

\section{Documentation}

During the implementation of the research, starting from taking water hyacinth in the river to alleviating test objects (briquettes) the research always documents it, with the aim that from the documentation that researchers can take, hopefully later it can be useful in preparing reports[13].

5. Observation

Observation is data collection where researchers go directly to the Lamongan Islamic University laboratory to conduct direct research on the utilization of used tire ore waste on the AC-WC asphalt mixture[14][15]. From this, it is hoped that researchers will be able to find out how the effect of adding waste tire ore to the asphalt mixture and so that researchers can find out various kinds of work process situations (conditions) in the laboratory[16][8].

\section{Secondary Data Collection}

Secondary data is data obtained indirectly, for example from previous research references and references from literature books[17]. In this case the researcher collects data by visiting the library, study center, archive center, journal or reading many books related to his research[18][19].

7. Data Analysis

After doing research on the addition of a mixture of waste tire ore to the hot asphalt mixture, researchers can compare the results of the Marshall Properties test using 4 types of test objects in which 4 test objects are given before being added and after being given additional waste tire ore[20][21]. After testing and research, the results will be obtained, which is then carried out by making mathematical modeling with the help of MS Excel 2013 software to determine the relationship between the additional levels of waste tire ore, (i) asphalt quality; and, (ii) values of marshall properties[22]. The final result is a mathematical model of the relationship between the addition of waste tire ore: (i) asphalt 
quality (penetration; softening point; flash point and burning point of asphalt); and, (ii) the values of the marshall properties. The results of data analysis are used as the basis for drawing a final conclusion[19].

\section{Results and Discussion}

\subsection{Marshall Test Test Process}

Marshall test refers to SNI 06-2489-1991, with the final test results to determine the value of marshall stability, flow, marshall quotient, voids filled with bitumen, voids in mineral aggregates and voids in mineral aggregates[23]. air voids (voids in mix) where the hot asphalt mixture is added with waste tire ore [24].

4.1.1 Relationship of Waste Tire Variation with Marshall Stability

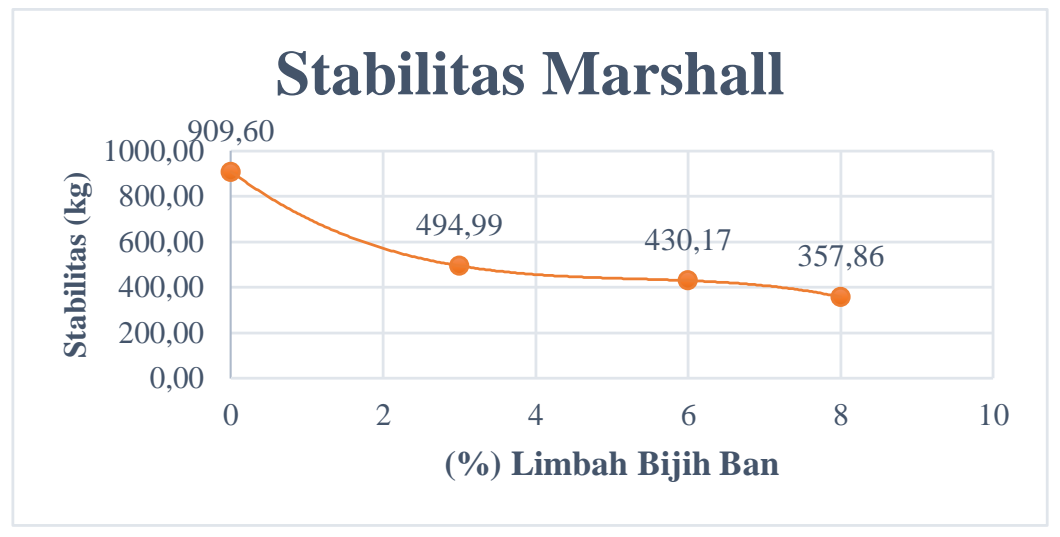

Figure 1. Graph of Relationship \% Waste Tires with Marshall Stability

Source: Integrated Laboratory Research, 2021

Stability is the ability of the pavement to accept a load until yielding occurs. From the marshall stability graph, the highest value is obtained with a value of $909.60 \mathrm{~kg}$.

\subsubsection{Relationship of Tire Ore Waste Variation with Plastic Melt (FLOW)}

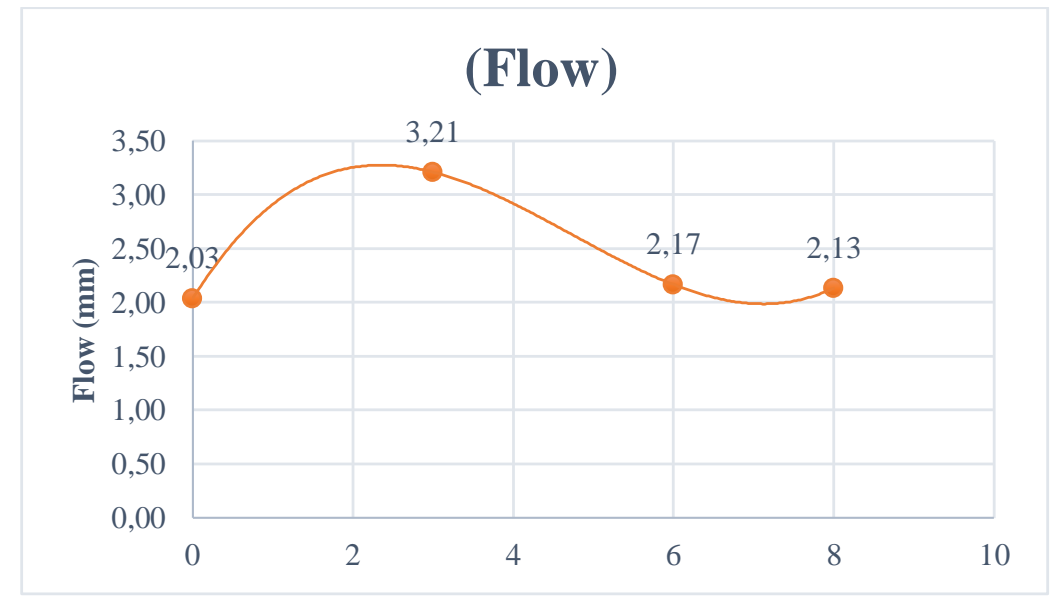

Figure 2. Graph of Relationship between Flow Model and Tire Ore Waste Source: Integrated Laboratory Research, 2021 
Yield (flow) is a vertical deformation that occurs from the beginning of loading until the stability condition decreases, which indicates the amount of deformation that occurs in the pavement layer due to resisting the load it receives. The amount of flow value is expressed in $\mathrm{mm}$ or 0.01 ". The flow value is influenced by asphalt content, asphalt viscosity, aggregate gradation, compaction amount and temperature. From the flow chart above, the highest asphalt flow value is $3.21 \mathrm{~mm}$.

\subsubsection{Relationship of waste tire ore with VMA}

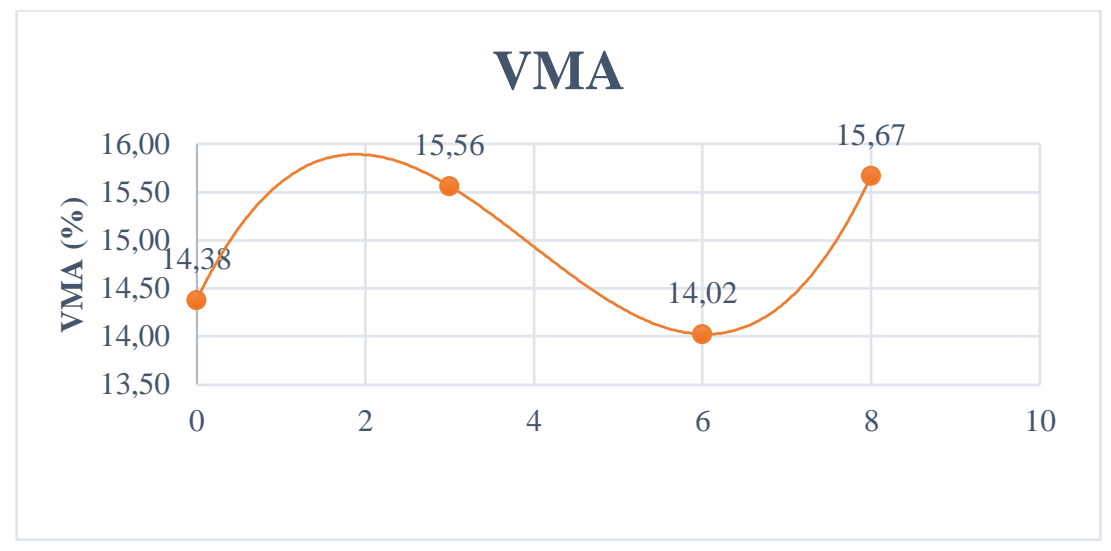

Figure 3. Graph of VMA Relationship Model with Tire ore Waste Source: Integrated Laboratory Research, 2021

VMA is the intergranular space occupied by asphalt and air in the compacted asphalt mixture. In the component diagram, it is the sum of the air volume and the effective asphalt volume. From the VMA chart above, the highest VMA value is $15.67 \%$.

\subsubsection{Relationship between Tire Ore and VFWA}

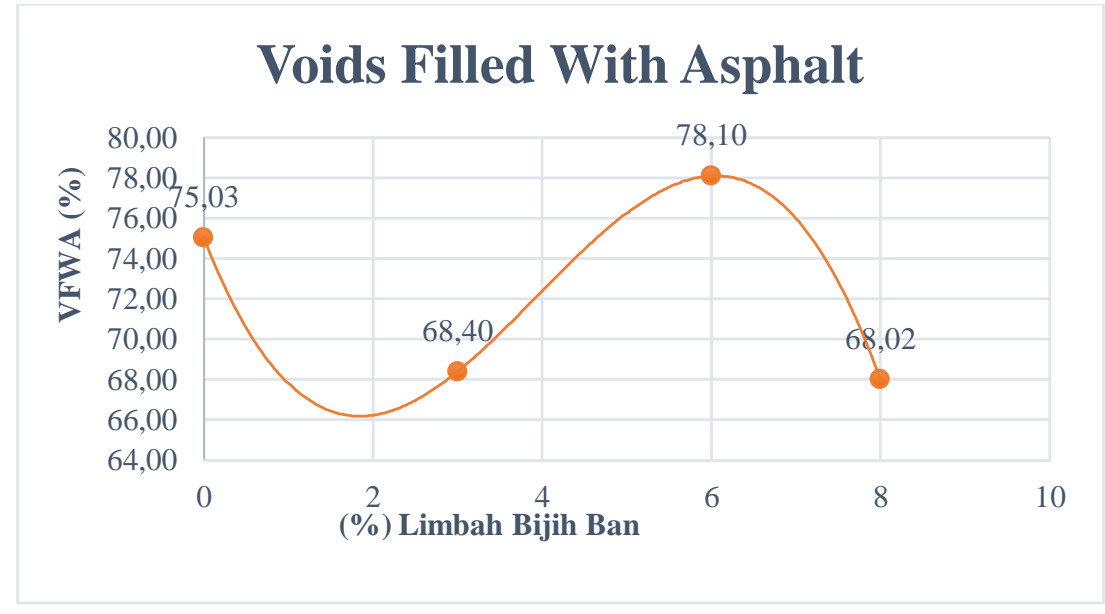

Figure 4. Graph of VFWA Relationship Model with Tire Ore Waste Source: Integrated Laboratory Research, 2021 
VFWA is the percent of voids between aggregate particles (VMA) filled with asphalt, excluding asphalt absorbed by aggregate. From the graph above, the highest value is $78.10 \%$.

4.1.3 Relationship of Tire Ore Waste and Density

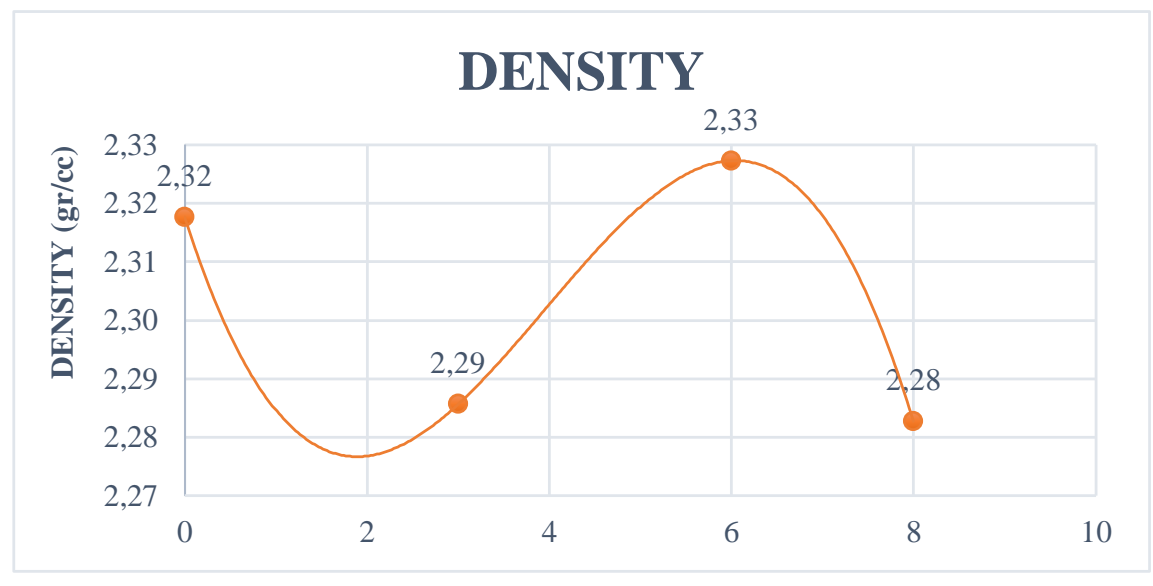

Figure 5 Graph of Density Relationship Model with Tire Ore Waste

Source: Integrated Laboratory Research, 2021

The density value is the volume weight value to show the density of the asphalt concrete mixture. From the dendity graph, the highest density is $2.33 \mathrm{gr} / \mathrm{cc}$.

\subsubsection{Relationship between Tire Ore Waste and VIM}

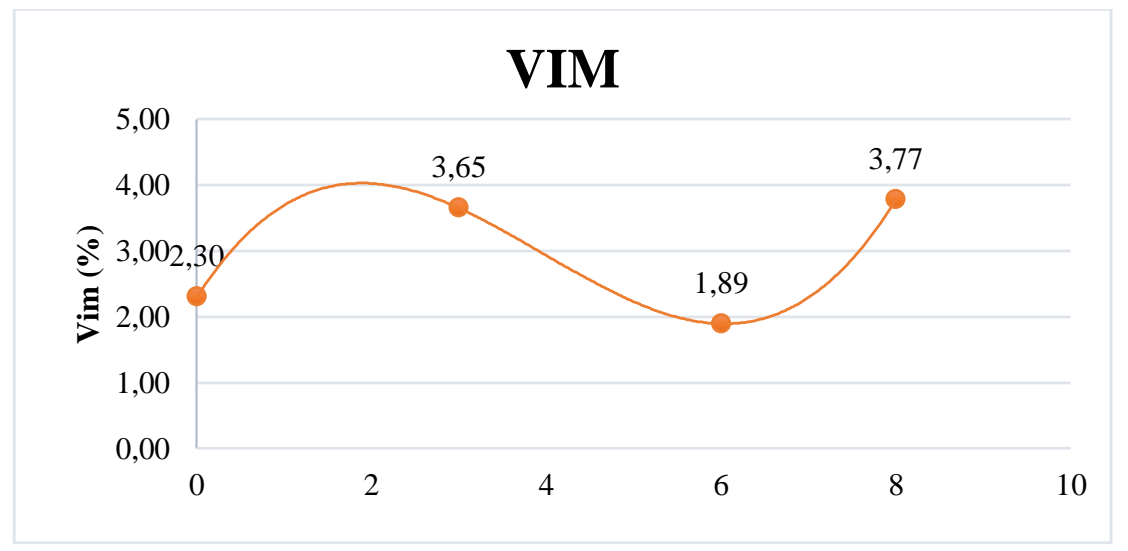

Figure 6 Graph of VIM Relationship Model with Tire Ore Waste

Source: Integrated Laboratory Research, 2021

Void in the Mix (VIM). VIM shows the percentage of voids in the mixture. The VIM value affects the durability of the asphalt aggregate mixture, the higher the VIM value indicates the larger the voids in the mixture so that the mixture is porous. From the VIM chart above, the highest score is $3.77 \%$. 


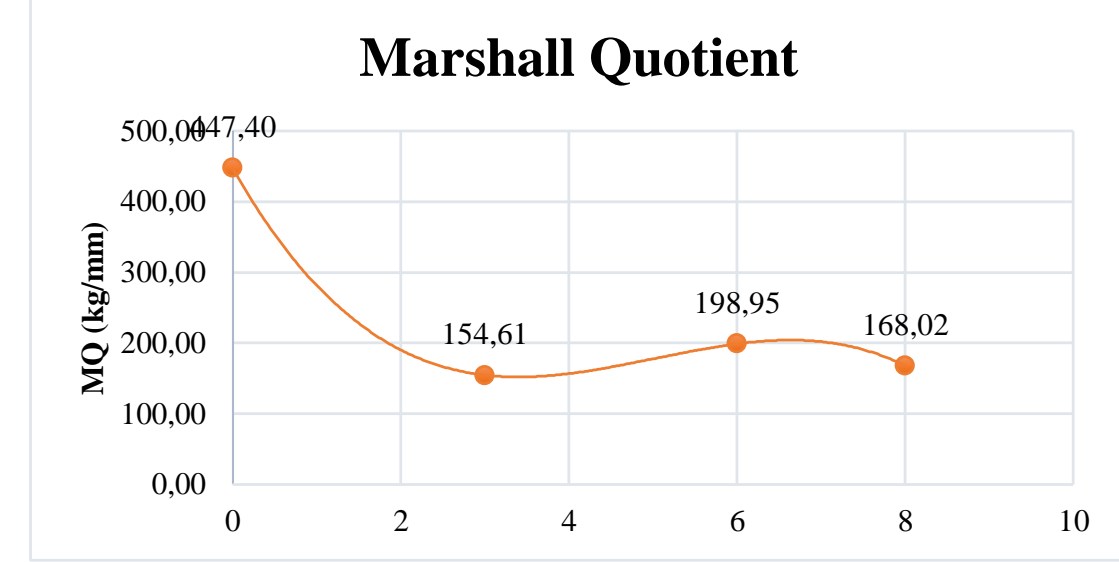

Figure 7 Graph of MQ Relationship Model with Tin Waste

Source: Integrated Laboratory Research, 2021

Marshall Quotient (MQ). The MQ value expresses the stiffness properties of a mixture. If the MQ value is too high, the mixture will tend to be too stiff and easy to crack. Conversely, if the MQ value is too low, the pavement becomes too flexible and tends to be less stable. From the MQ graph above, the highest value is $447.40 \mathrm{~kg} / \mathrm{mm}$.

\section{Conclusions and Suggestions}

\subsection{Conclusion}

From the results of tests conducted regarding the effect of mixing tire ore on hot asphalt, the following conclusions can be drawn:

1. The process of making AC-WC asphalt specimens with the addition of tire ore waste as an asphalt mixture includes; (1) Planning the work mix (Job Mix Formula), (2) The process of testing the stacked object, (3) The process of testing the asphalt, (4) The process of mixing the test object, (5) The process of printing the test object.

2. Of the 3 variations used, namely from the average value of variation $0 \%, 3 \%, 6 \%$ and $8 \%$ addition of waste tire ore for the highest variation value of $3 \%$, with a stability value of $494.99 \mathrm{~kg}$, VFWA with the value of $68.40 \%$, VIM with a value of $3.65 \%$, with a value of FLOW with a value of $3.21 \mathrm{~mm}$, Marshall Quotient with a value of $154.61 \mathrm{~kg} / \mathrm{mm}$, VMA with a value of $15.56 \%$ and Density with a value of $2.29 \mathrm{gr} / \mathrm{cc}$. Then it was concluded that the addition of used tire ore was not in accordance with the recommended standard because the higher the percentage value in the mixture, the lower the Marshall stability value. 


\section{Suggestion}

1. It is hoped that it can be used as a reference for future research, so that there are no errors in conducting research.

2. So that future researchers will be more careful in conducting research, both during the calculation process, weighing, making test objects, and testing test objects.

\section{Reference}

[1] Mahmuda, Sumiati, and T. Lina Flaviana, "Asphalt Modified Plastic Waste to Defend Damage in Asphalt Concrete (Ac-Wc)," in Journal of Physics: Conference Series, 2019, doi: 10.1088/1742-6596/1167/1/012011.

[2] Istiar, T. J. W. Adi, Sutikno, Rahmat, M. Kencanawati, and I. Siara, "The effect of laterite stone as filler on marshall stability hot mix asphalt AC-WC," MATEC Web Conf., 2019, doi: 10.1051/matecconf/201925801003.

[3] A. V. R. Sihombing, B. S. Subagio, E. S. Hariyadi, and A. Yamin, "Development of resilient modulus model proposed for bio-asphalt as modifier in asphalt concrete containing reclaimed asphalt pavement," Int. J. GEOMATE, 2020, doi: 10.21660/2020.71.68349.

[4] H. A. A. Hasyir and S. B. Wasono, "Analysis Mixed Layer Asphalt Surface as Asbuton Ac-Wc Characteristics of Marshall," IJIEEB Int. J. Integr. Educ. Eng. Bus. , 2020, doi: 10.29138/ijieeb.v3i2.1173.

[5] D. Kartikasari and S. D. Hartantyo, "PENGGANTIAN FILLER DENGAN FLY ASH DAN SERBUK BATU BATA PADA CAMPURAN ASPAL (AC-WC) FILLER REPLACEMENT WITH FLY ASH AND BRICK POWDER IN MIX OF ASPHALT (AC-WC),"UKaRsT, 2017, doi: 10.30737/ukarst.v1i1.259.

[6] Y. R. R. Saragi, P. Lumbangaol, R. A. Sidabutar, and B. S. Siahaan, "Marshall Characteristics in Asphalt Concrete -Wearing Corse (AC-WC) in Various Length and Temperature Submersion," in Procedia Engineering, 2017, doi: 10.1016/j.proeng.2017.01.460.

[7] G. Tarigan et al., "Effects of aggregate abrasrion values to marshall properties of Asphalt Concrete AC- WC," Int. J. Eng. Technol., 2018, doi: 10.14419/ijet.v7i3.2.18758.

[8] D. Nawir and A. Z. Mansur, "The impact of hdpe plastic seeds on the performance of asphalt mixtures," Civ. Eng. J., 2021, doi: 10.28991/cej-2021-03091744.

[9] M. Tumpu, M. W. Tjaronge, A. R. Djamaluddin, A. A. Amiruddin, and L. One, "Effect 
of limestone and buton granular asphalt (BGA) on density of asphalt concrete wearing course (AC-WC) mixture," in IOP Conference Series: Earth and Environmental Science, 2020, doi: 10.1088/1755-1315/419/1/012029.

[10] S. Sunarjono, N. Hidayati, M. R. W. Ardianto, and A. Magfirona, "Analysis of AC-WC design material using reclaimed asphalt pavement," Civ. Eng. Archit., 2020, doi: 10.13189/cea.2020.080310.

[11] S. R. Harnaeni, F. P. Pramesti, A. Budiarto, A. Setyawan, M. I. Khan, and M. H. Sutanto, "Study on structural performance of asphalt concrete and hot rolled sheet through viscoelastic characterization," Materials (Basel)., 2020, doi: 10.3390/ma13051133.

[12] S. D. Hartantyo and B. Hermanto, "PENGARUH PENGGUNAAN KRIKIL MANTUP SEBAGAI BAHAN PERKERASAN JALAN (AC-WC)," UKaRsT, 2019, doi: 10.30737/ukarst.v3i2.605.

[13] M. Mukhlis, L. Lusyana, E. Suardi, and F. Adibroto, "Kinerja Marshall Immersion pada Campuran Asphalt Concrete Wearing Course (AC-WC) dengan Penambahan Cangkang Sawit sebagai Substitusi Agregat Halus," J. Ilm. Rekayasa Sipil, 2018, doi: 10.30630/jirs.15.2.130.

[14] Irianto and M. Tumpu, "COMPRESSIVE STRENGTH OF ASPHALT CONCRETE WEARING COURSE MIXTURE CONTAINING WASTE PLASTIC POLYPROPYLENE," ARPN J. Eng. Appl. Sci., 2020.

[15] I. N. A. Thanaya, I. G. R. Puranto, and I. N. S. Nugraha, "Studi Karakteristik Campuran Aspal Beton Lapis Aus (AC-WC) Menggunakan Aspal Penetrasi 60/70 dengan Penambahan Lateks," MEDIA Komun. Tek. SIPIL, 2016, doi: 10.14710/mkts.v22i2.12875.

[16] N. Suaryana, I. Susanto, Y. Ronny, and I. R. Sembayang, "Evaluasi Kinerja Campuran Beraspal dengan Bitumen Hasil Ekstraksi Penuh dari Asbuton," MEDIA Komun. Tek. SIPIL, 2018, doi: 10.14710/mkts.v24i1.18175.

[17] Y. Astor, A. M. S. Sufanir, and W. Z. Utari, "The characteristics of Asphalt ConcreteWearing Course (AC-WC) mixture using Buton Rock Asphalt (BRA) with Oily Sludge (OS) as a rejuvenator," in IOP Conference Series: Materials Science and Engineering, 2020, doi: 10.1088/1757-899X/732/1/012029.

[18] E. Sembiring, H. Rahman, and Y. M. Siswaya, "Utilization of polypropylene to substitute Bitumen for asphalt concrete wearing course (Ac-Wc)," Int. J. GEOMATE, 2018, doi: 10.21660/2018.42.17347.

[19] R. Handayani and A. F. Wicaksono, "USAGE OF RECLAIMED ASPHALT 
PAVEMENT AS A MIXTURE MATERIAL OF ASPHALT CONCRETE WEARING COURCE (ACWC)," J. Innov. Civ. Eng., 2021, doi: 10.33474/jice.v1i2.10998.

[20] Chaira and E. Mawardi, "Utilization of palm shells fly ash as filler on the mixture of Asphalt Concrete Wearing Course (AC-WC)," in IOP Conference Series: Earth and Environmental Science, 2019, doi: 10.1088/1755-1315/325/1/012004.

[21] S. Sunarjono, N. Hidayati, and A. I. Pratama, "KETAHANAN CAMPURAN AC-WC MENGGUNAKAN LATEKS TERHADAP AIR,” J. Transp., 2020, doi: 10.26593/jtrans.v20i2.4105.125-136.

[22] W. A. R. Hakim, "Mixture Composition Analysis Of Reclaimed Asphalt Pavement (RAP) As Asphalt Concrete - Wiring Course (AC-WC) Layer Against Marshall Characteristic," J. World Conf., 2019, doi: 10.29138/prd.v2i1.134.

[23] M. Sadillah, M. Zainul Arifin, and A. Wicaksono, "FLY ASH AS FILLER USED FOR CHARACTERISTICS OF MARSHALL ASPHALT CONCRETE WEARING COURSE (AC-WC)," J. Rekayasa Sipil dan Lingkung., 2018, doi: 10.19184/jrsl.v2i01.6425.

[24] D. E. Intari, W. Fathonah, and B. Saputro, "Performance of asphalt concrete mixture (AC-WC) using asphalt added with the waste of rice husk ash," in IOP Conference Series: Materials Science and Engineering, 2019, doi: 10.1088/1757899X/673/1/012037. 